\title{
Leptospirosis an Increase Disease in Albania
}

\author{
Ali. E; Abazaj. E ${ }^{1}$, Hysaj (Vila) $B^{2}$ \\ Institute of Public Health, Tirana, Albania
}

\begin{abstract}
Leptospirosis is an important public health problem worldwide and in Albania too. Human infection caused by Leptospiraspp usually occurs through direct or indirect exposure to urine of an infected animal. Infection is often ascribed to occupational/recreational exposures mainly associated with male gender. This is a laboratory-based descriptive study of patients clinically suspected for Leptospirosis. There were tested febrile patients in Institute of Public Health, Tirana Albania, during the periods 2010-2014. Serums were screened by ELISA test for antibodies IgM and IgG. We have analyzed 360 suspected cases during 5 years. The seroprevalence of all cases resulted to be $38.8 \%$. Men were the most predominant cases with $90 \%$ of all samples compared to women 10\%. Average age was 44.62 with min-max 17 to 81 years old. The positivity of men resulted 64.46\%. A significance level have seen between the men and diseases for CI 95\% [1.2325 to 2.2297], OR 1.6577, $p=0.0008$. Based to the data for the profession the most affected were the farmers in $56 \%$ of cases and the mechanics in $12.9 \%$ of cases. The positivity was more frequent during summerautumn in $75 \%$ of cases. Conclusion: This study reveals a marked increased of Letospirosis. The male were more affected from this infection due to of occupational profile. So this infection should receive the attention of the health authorities in early diagnose for a better prevention.
\end{abstract}

Keywords: Leptospirosis, IgM and IgG, ELISA, prevalence, disease

\section{Introduction}

Leptospirosis is a zoonotic bacterial disease of increasing prevalence, a worldwide distribution, and with potentially serious consequences for human and animal health [1]-[2]. It is an endemic disease of domestic and wild animals [3]. In humans Leptospirosis is an occupational disease for farmers, abattoir workers, butchers, veterinarians, pet traders, hunters, rodent control workers, and other occupations requiring frequent contact with animals ([4]-[5]. Due to the fact that leptospires survive longer in warm and humid environments [1], such as in tropical climates, occupations that involve indirect contact with contaminated wet soil or water are at highest risk [5]. In addition to occupationally exposed groups, urban slum dwellers in areas with poor sanitation are communities at particularly high risk [6]. Infection associated with outdoor recreational exposure, international travel, especially to endemic areas in the tropics, and flooding is increasing [7]-[8]. Leptospirosis is caused by a bacterium of the genus Leptospiraspp. Leptospires are motile, obligate aerobic spirochaetes with an optimum growth temperature of $28-30^{\circ} \mathrm{C}$ that have characteristics of both Gram-negative and Gram-positive bacteria [9]-[10]. Transmission occurs from exposure to urine or aborted tissues of infected animals, either directly or via contact with contaminated water or soil [4].

Leptospiraspp persist in a humid environment (i.e. alkaline soil and water) for months or years [11]. The infection outcome varies with the grade of adaptation of the serovar type to the infected mammal species and is probably due to direct pathogen effects and (genetically determined) hostimmune responses [2]. Commonly each serovar is adapted toone or more hosts.

The clinical presentation of leptospirosis in humans ranges from asymptomatic to lethal, with a broad spectrum of clinical signs and symptoms [1] depending on the infecting serovar, age, health and Immunological competence [12].
The World Health Organization (WHO) has estimated that the annual incidence of leptospirosis is $0.1-1$ case/100,000 people in temperate non-endemic areas, and 10-100 cases/100,000 people in humid, tropical, endemic areas [13][14]. Leptospirosis has been recognized as an (re-)emerging global public health problem due to the increased incidence in both developing and developed countries [15].

\section{Materials and Methods}

Samples were obtained from patients admitted to the University Hospital Centre "Mother Theresa" TiranaAlbania during January 2010 to December 2014, with a history and clinical manifestations suggestive of leptospirosis [16], including fever, jaundice, anorexia, headache, conjunctival suffusion, myalgia, and abdominal pain. For each person was used a questionnaire that containing information about demographic data and clinical sign. A blood sample of $5 \mathrm{ml}$ for each person was collected in tubes and immediately was transported to Parasitological Laboratory, Institute of Public Health, for sera isolation. Sera samples were stored at $-20^{\circ} \mathrm{C}$ until use The IgM ELISA has been recommended by the World Health Organization (WHO) as a diagnostic test for the serodiagnosis of leptospirosis where healthcare resources are limited [17], although its reported accuracy is variable. A number of studies have reported that IgM ELISA has high sensitivity and specificity for the diagnosis of acute leptospirosis [18] [19]. The chosen test is IgM ELISA (Institute Virion\Serion $\mathrm{GmbH}$, Warburg, Germany). Interpretation of results for Serion ELISA classic Leptospira IgM was as follows: antileptospira $\operatorname{IgM}<15 \mathrm{IU} / \mathrm{ml}$ gives a negative result suggesting no evidence of a recent infection, $15-20 \mathrm{IU} / \mathrm{ml}$ gives a borderline result suggesting that may be a recent infection and $\geq 20 \mathrm{IU} / \mathrm{ml}$ gives a positive result which is interpreted as a recent or current infection.Data were entered and analyzed by using Statistical Packages for Social Sciences (SPSS) Version 16. 


\section{International Journal of Science and Research (IJSR) \\ ISSN (Online): 2319-7064}

Index Copernicus Value (2013): 6.14 | Impact Factor (2014): 5.611

\section{Results}

A total of 360 patients admitted to the University Hospital Centre "Mother Theresa" Tirana-Albania during January 2010 to December 2014 for diagnosis of suspected leptospirosis were investigated. Diagnosis for leptospirosis was confirmed in $38.8 \%$ of cases and incidence of our country varied from 0.6 to 0.4 cases $/ 100.000$ population [20]. In our study the positivity of infection resulted $64.46 \%$. All patients were categorized into six age groups. Min age resulted to be 17 years old and max 81 years old. Average age of all patients was 44.62. Men were the most predominant sex in our study with $90 \%$ of all samples compared to women $10 \%$. Mean of infected men every year were 25.4. A significance level have seen between the men and diseases for CI 95\% [1.2325 to 2.2297], OR 1.6577, $\mathrm{p}=0.0008$. Table below present Analysis Univariante of Logistic Regression.

Table 1: Positivity divided by age and sex. Un analyses univarianteof logistics regression

\begin{tabular}{|c|c|c|c|c|c|}
\hline $\begin{array}{c}\text { Age } \\
\text { groups }\end{array}$ & $\begin{array}{c}\text { Number } \\
(360)\end{array}$ & Negative & Positive & $\begin{array}{c}\text { Odds ratio } \\
(95 \%)\end{array}$ & $p$ value \\
\hline $15-25$ & 5 & 4 & 1 & ref & \\
\hline $26-35$ & 37 & 29 & 8 & $0.9(0.088$ to 9.2$)$ & 0.08 \\
\hline $36-45$ & 84 & 61 & 23 & $0.6(0.07$ to 6.2$)$ & 0.7 \\
\hline $46-55$ & 143 & 54 & 89 & $0.1(0.016$ to 1.3$)$ & 0.09 \\
\hline $56-65$ & 74 & 63 & 11 & $1.4(0.1$ to 14$)$ & 0.7 \\
\hline$>65$ & 17 & 9 & 8 & $0.2(0.02$ to 3.0$)$ & 0.2 \\
\hline Sex & & & & & \\
\hline Female & 36 & 29 & 7 & ref & \\
\hline Male & 324 & 191 & 133 & $0.3(0.14$ to 0.8$)$ & 0.015 \\
\hline \multicolumn{7}{|r|}{}
\end{tabular}

This infection presents a broad spectrum of clinical signs and symptoms. Some of the most common clinical signs are presented in the table below. Mortality was observed in $1.8 \%$ of positive cases with Leptospira spp.

Table 2: Clinical signs of patients in percentage

\begin{tabular}{|c|c|}
\hline Clinical sign & Percentage \\
\hline Myalgia & $88.7 \%$ \\
\hline Fever $38.2^{\circ} \mathrm{C}$ & $86 \%$ \\
\hline Fatigue & $84.1 \%$ \\
\hline Headache & $71 \%$ \\
\hline Jaundice & $67.2 \%$ \\
\hline Vomiting and abdominal pain & $56 \%$ \\
\hline Respiratory sign & $29.9 \%$ \\
\hline Renal insufficiency & $31.7 \%$ \\
\hline Mortality & $1.8 \%$ \\
\hline
\end{tabular}

Table 3 presents sociodemographic characteristics of our study patients. As seen in this table the majority of positive cases lived in rural area $88 \%$ compared to them of urban area $12 \%$.
Table 3: Sociodemographic characteristics among study patients

\begin{tabular}{|c|c|}
\hline Characteristics of study patients & Percentage of positive cases \\
\hline Residence & \\
\hline Rural & $88 \%$ \\
\hline Urban & $12 \%$ \\
\hline Maritual status & $9 \%$ \\
\hline Single & $91 \%$ \\
\hline Married & \\
\hline Profession & $56 \%$ \\
\hline Farmer & $12.9 \%$ \\
\hline Mechanics & $3.2 \%$ \\
\hline Fisher man & $27.9 \%$ \\
\hline Unknow & \\
\hline Seasonality & $75 \%$ \\
\hline Summer & $25 \%$ \\
\hline Winter & \\
\hline Source of infection & $65 \%$ \\
\hline Contact with mice & $35 \%$ \\
\hline Unknown source of infection &
\end{tabular}

Only $9 \%$ of single men resulted to be positive for Leptospiraspp and $91 \%$ of them were married. Based to the data for the profession the most affected were the farmers in $56 \%$ of cases and the mechanics in $12.9 \%$ of cases. The positivity was more frequent during summer-autumn in $75 \%$ of cases. $65 \%$ of them said that have seen mice near the place were they were staying or have contact with them. No significant level has seen between sociodemographice characteristics among study patients and disease for CI $95 \%$ $\mathrm{p}$ value resulted to be $>0.05$ for all data.

\section{Discussion}

Human leptospirosis is considered an increasing disease in Albania during this decade. The prevalence of this infection during five years resulted $38.8 \%$ with incidence from 0.4 to 0.6 cases/100.000 population [20]. Considering these low seropositivity, findings in the present study were unexpectedly high and are comparable with findings in tropical and subtropical countries of high endemicity [21] [22].

As many other zoonotic disease, the risks of leptospirosis infection are multi factorial and involve environmental, social, economic factors and host. Climate changes that are occurring around the world and in our country too, explain the increased number of suspicious and laboratoryconfirmed cases.In our country there are no studies regarding the incidence of infection caused by Leptospira spp. New cases are reported throw the Alert System set up at the Institute of Public Health (IPH), where districts make the reporting of suspicious or confirmed laboratory cases. Suspicious cases came to IPH for further examination and confirmation of diagnosis.Serological methods are most useful for the diagnosis of Leptospira [23]. Serological tests used are based on the detection of $\operatorname{IgM}$ and $\operatorname{IgG}$ immunoglobulins. Enzyme-linked immunosorbent assay (ELISA) is a serological test that is often used for detection (screening) [24], 2005), and diagnosis of infections by Leptospira in countries with limited health resources [25]. The incidence in recent years in our country is estimated approximately $0.4-0.6$. This value is lower than some areas 


\section{International Journal of Science and Research (IJSR) \\ ISSN (Online): 2319-7064}

Index Copernicus Value (2013): 6.14 | Impact Factor (2014): 5.611

of the Balkans and Europe. Serbia and Montenegro incidence is estimated to be 1 and for Croatia it is 1.8. Italy incidence is lower approximately 00:13 and yet Germany has a lower incidence 0.06 [26]. The prevalence in this study resulted in $38.8 \%$ due to increased number of suspicious and positive cases. During the years 2011-2013 in our country there were flooding in some areas particularly in northwestern areas. This situation was the reason of the raised number of leptospirosis cases. Age groups 46-55 years present the majority of positive cases. This number is high for this age group because this age is most active in carrying out various tasks that have the risk of contamination from infection caused by Leptospira spp. One other factor contributing to the high rate of this seropositivity could be the study population: nearly all individuals tested were men aged between 18 and $>65$ years. The predominance of positive men among clinical cases in our study were well recognized also by Ciceroni and Katz in their study [27]-[28], and has been explained by their greater tendency to participate in outdoor activities at high risk for exposure [29].Similarly, case rates among adults between 20 and 50 years of age are also consistently the highest reported by Brockmann [30]. Men are most affected by this infection due to a higher exposure to risk factors so they are more vulnerable than women. The third age group is $>61$ years with $23.2 \%$ of the cases examined. Highest prevalence of positive cases is found in rural area compared to urban area. This is due to the poor conditions in rural areas, fieldworks, frequent contacts with infected animals, contacts with contaminated environments (as land, water, springs, streams and ponds) and with urine of infected animals from Leptospira spp. Leptospirosis is considered an occupational disease (related to work) that affects farmers, veterinarians, sewer maintainers etc. The lack of protective measures such as gloves, boots and special clothes is the main cause of increasing number of positive cases. The occupations that are the most exposed are: farmers, divers or mechanics, those of the fish farmers and sewage and canal workers that are in direct contact with animals and contaminated water. The largest number of persons affected from rural areas results to be farmers $56 \%$ of them. Fish farmers are $3.2 \%$ of them, mechanical or driver by profession are $12.9 \%$ and $65 \%$ have been in contact with mice near areas that live or work.

\section{Conclusion}

This study reveals a marked increased of Letospirosis. The male were more affected from this infection due to of occupational profile. So this infection should receive the attention of the health authorities in early diagnose for a better prevention.

\section{References}

[1] Levett, P.N. Leptospirosis. Clinical Microbiology Reviews14, 296-326, 2001.

[2] Bharti, A.R., Nally, J.E., Ricaldi, J.N., Matthias, M.A., Diaz, M.M., Lovett, M.A., Levett, P.N., Gilman,R.H., Willig, M.R., Gotuzzo, E., Vinetz, J.M. Leptospirosis: a zoonotic disease of global importance. Lancet Infectious Diseases3, 757-771, 2003.
[3] Thornley, C.N., Baker, M.G., Weinstein, P., Maas, E. W. Changing epidemiology of human leptospirosis in New Zealand. Epidemiol. Infect. 128, 29-36, 2002.

[4] Hartskeerl RA, Collares-Pereira $M$ and Ellis WA. Emergence, control and re-emerging leptospirosis: dynamics of infection in the changing world. Clinical Microbiology and Infection 17, 494-501, 2011.

[5] Musso D and La Scola B. Laboratory diagnosis of leptospirosis: A challenge. Journal of Microbiology, Immunology and Infection 46, 245-52, 201, 2013.

[6] Abela-Ridder B, Sikkema R and Hartskeerl RA. Estimating the burden of human leptospirosis. International Journal of Antimicrobial Agents 36, S5-7, 2010.

[7] Lau C, Smythe L and Weinstein P.: Leptospirosis: an emerging disease in travellers. Travel Medicine and Infectious Disease 8, 33-9, 2010a.

[8] Lau CL, Smythe LD, Craig SB and Weinstein P. Climate change, flooding, urbanisation and leptospirosis: Transactions of the Royal Society of Tropical Medicine and Hygiene 104, 631-8, $2010 \mathrm{~b}$.

[9] Faine, S., Adler, B., Bolin, C., Perolat, P. Leptospira and Leptospirosis. MediSci, 2nd ed. Melbourne, 272.

[10] Haake, D.A., Chao, G., Zuerner, R.L., Barnett, J.K., Barnett, D., Mazel, M., Matsunaga, J., Levett, P.N., Bolin, C.A. 2000: The leptospiral major outer membrane protein LipL32 is a lipoprotein expressed during mammalian infection. Infection and Immunity 68, 2276-2285, 1999.

[11] Miller, D.A., Wilson, M.A., Beran, G.W. Relationships between Prevalence of Leptospira-Interrogans in Cattle, and Regional, Climatic, and Seasonal Factors. American Journal of Veterinary Research 52, 1766-1768. 1991.

[12] Adler, B., de la Pena Moctezuma, A. Leptospira and leptospirosis. Veterinary Microbiology 140, 287-29. 2010.

[13] Abgueguen P, Delbos V, Blanvillain J, Chennebault JM, Cottin J, Fanello S and Pichard E. Clinical aspects and prognostic factors of leptospirosis in adults. Retrospective study in France. Journal of Infection 57, 171-8. 2008.

[14] Sethi S, Sharma N, Kakkar N, Taneja J, Chatterjee SS, Banga SS and Sharma M. Increasing trends of leptospirosis in northern India: A clinicoepidemiological study. Plos Neglected Tropical Diseases 4, e579. 2010.

[15] Vijayachari P, Sugunan AP and Shriram AN. Leptospirosis: an emerging global public health problem. Journal of Biosciences 33, 557-69. 2008.

[16] Edwards CN, Nicholson GD, Hassell TA,Everard COR, Callender J, Leptospirosis in Barbados: a clinical study. WestIndian Med J 39: 27-34. 1990.

[17] World Health Organization/International. Leptospirosis Society Human leptospirosis: guidancefor diagnosis, surveillance and control 2003.

http://whqlibdoc.who.int/hq/2003/WHO_CDS_CSR_EP H 2002.23.pdf

[18] Ooteman MC, Vago AR, Koury MC. Evaluation of MAT, IgM ELISA and PCR methods for the diagnosis of human leptospirosis. J Microbiol Methods. 65:247257. 2006. [PubMed]

[19]Zochowski WJ, Palmer MF, Coleman TJ. An evaluation of three commercial kits for use as screening methods 


\section{International Journal of Science and Research (IJSR) \\ ISSN (Online): 2319-7064}

Index Copernicus Value (2013): 6.14 | Impact Factor (2014): 5.611

for the detection of leptospiral antibodies in the UK. J ClinPathol. 54:25-30. 2001: [PMC free article] [PubMed].

[20] L. Alla et. al. Epidemiological overview of human leptospirosis in Albania. $2^{\text {nd }}$ ELS meeting on Leptospirosis and other rodent borne haemorrhagic fevers.Amsterdam. 16-18 April 2015

[21] Vijayachari P, Sugunan AP, Shriram AN. Leptospirosis: an emerging global public health problem. J Biosci; 33(4):557-69. 2008: http://dx.doi.org/10.1007/s12038008-0074-z PMid:19208981.

[22] Georgios Pappas' Photini Papadimitriou' VasilikiSiozopoulou, Leonidas Christou' NikolaosAkritidis. The globalization of leptospirosis: worldwide incidence trends. International Journal of Infectious Diseases. Volume 12, Issue 4, 351-357. 2008.

[23] Toyokawa T, Ohnishi M and Koizumi N. Diagnosis of acute leptospirosis. Expert Review of Anti-infective Therapy; 9, 111-21. 2011.

[24] Aslantaş Ö. Determination of the Seroprevalence of Leptospirosis in Cattle by MAT and ELISA in Hatay, Turkey. Turkish Journal of Veterinary and Animal Sciences; 29, 1019-24. 2005.

[25] World Health Organization.:Human leptospirosis. Guidance for diagnosis, surveillance and control. http://whqlibdoc.who.int/hq/2003/WHO_CDS_CSR_EP H_2002.23.pdf (accessed September 2013), WHO, Geneva. 2003.

[26] W Poeppl, M J Orola, H Herkner, M Müller, S Tobudic, A Faas, G Mooseder, F Allerberger, H Burgmann. High prevalence of antibodies against leptospira spp. in male austrian adults: a cross-sectional survey, April to June 2009. Eurosurveillance, Volume 18, Issue 25, 20 June 2013.

[27] Ciceroni L, Stepan E, Pinto A, Pizzocaro P, Dettori G, Franzin L, et al. Epidemiological trend of human leptospirosis in Italy between 1994 and 1996. Eur J Epidemiol. $16 \quad$ (1):7986.http://dx.doi.org/10.1023/A:1007658607963 PMid: 10780347. 2000.

[28] Katz AR, Buchholz AE, Hinson K, Park SY, Effler PV. Leptospirosis in Hawaii, USA, 1999-2008. Emerg Infect Dis. 17(2):221-6. 2011.

[29] Radl C, Muller M, Revilla-Fernandez S, Karner-Zuser $S$, de Martin A, Schauer U, et al. Outbreak of leptospirosis among triathlon participants in Langau, Austria, 2010. Wien Klin Wochenschr; 123(23-24):7515.http://dx.doi.org/10.1007/s00508-011-0100-2 PMid: 22105111.2011.

[30] Brockmann S, Piechotowski I, Bock-Hensley O, Winter C, Oehme R, Zimmermann S, et al. Outbreak of leptospirosis among triathlon participants in Germany, 2006. BMC Infect Dis. 10:91. 2010. http://dx.doi.org/10.1186/1471-2334-10-91 PMid:20380736 PMCid:2858141. 